\title{
WestVirginiaUniversity
}

THE RESEARCH REPOSITORY @ WVU

West Virginia Agricultural and Forestry Experiment

Davis College of Agriculture, Natural Resources

Station Bulletins

And Design

$1-1-1908$

\section{Bacteria in Milk and Artificial Refrigeration for Dairymen}

\author{
J. H. Stewart
}

Horace Atwood

Follow this and additional works at: https://researchrepository.wvu.edu/ wv_agricultural_and_forestry_experiment_station_bulletins

\section{Digital Commons Citation}

Stewart, J. H. and Atwood, Horace, "Bacteria in Milk and Artificial Refrigeration for Dairymen" (1908). West Virginia Agricultural and Forestry Experiment Station Bulletins. 111.

https://researchrepository.wvu.edu/wv_agricultural_and_forestry_experiment_station_bulletins/111 @ WVU. It has been accepted for inclusion in West Virginia Agricultural and Forestry Experiment Station Bulletins by an authorized administrator of The Research Repository @ WVU. For more information, please contact ian.harmon@mail.wvu.edu. 



\section{WEST VIRGINIA UNIVERSITY \\ AGRICULTURAL EXPERIMENT STATION \\ MORGANTOWN, W. VA.}

\section{Bacteria in Milk and}

Artificial Refrigeration for

Dairymen

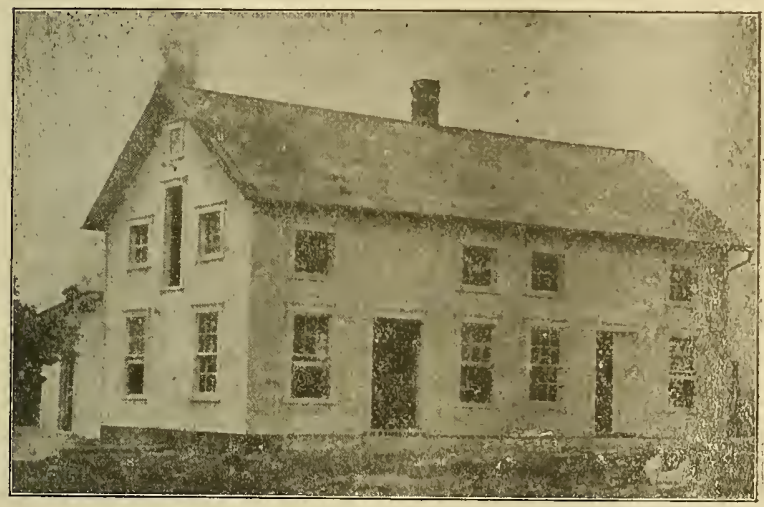

Datry House at Experiment Station.

BY J. H. STEWART AND HORACE ATWOOD.

[The Bulletins and Reports of this Station will be mailed free to any citizen of West Virginia upon written application. Address Director Agricultural Experiment Station, Morgantown, W. Va.] 


\section{THE REGENTS OF THE WEST VIRGINIA UNIVERSITY}

Name of Regent.

P. O. Address.

Hon. C. M. Вавв ........................... W. Va.

Hon. J. B. Finley................... Parkersburg, W. Va.

Hon. D. C. Galdaher.................. Charleston, W. Va.

Hon. E. M. Grant........................ Worgantown, W. Va.

Hon. C. E. Haworth..................Huntington, W. Va

Hon. C. P. MaNell...................Wheeling, W. Va.

Hon. L. J. Wildiams..................Lewisburg, W. Va. Hon. T. P. JАCoBs.................. New Martinsville, W. Va. Hon. J. R. Trotter...................Buckhannon, W. Va.

President of the Board of Regents............... R. TROTteR President of the University............... D. B. Purinton

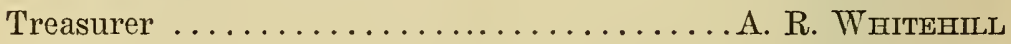
Auditor ............................... WhIтE

\section{STATION STAFF}

James H. Stewhrt, A. M......... Director and Agriculturist Bert H. Hite, M. S............. Vice Director and Chemist W. M. Munson, Рн. D.................. Horticulturist W. E. Rumsey, B. S. Agr .................. Entomologist Horace Atwood, M. S. Agr...........Assistant Agriculturist Fred E. Broors. ................. Associate Entomolgist Frank B. Kunst...................... Assistant Chemist Leicester Patton..................... Assistant Chemist Chas. E. Weakley, Jr . . . . . . . . . . Assistant Chemist W. J. Wніте........................... Bookkeeper

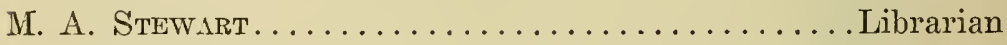
Alice Engle $\ldots \ldots \ldots \ldots \ldots \ldots \ldots \ldots$. Stenographer

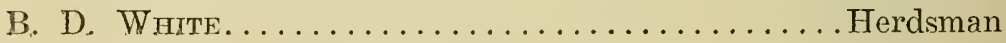


Digitized by the Internet Archive in 2010 with funding from

Lyrasis Members and Sloan Foundation 


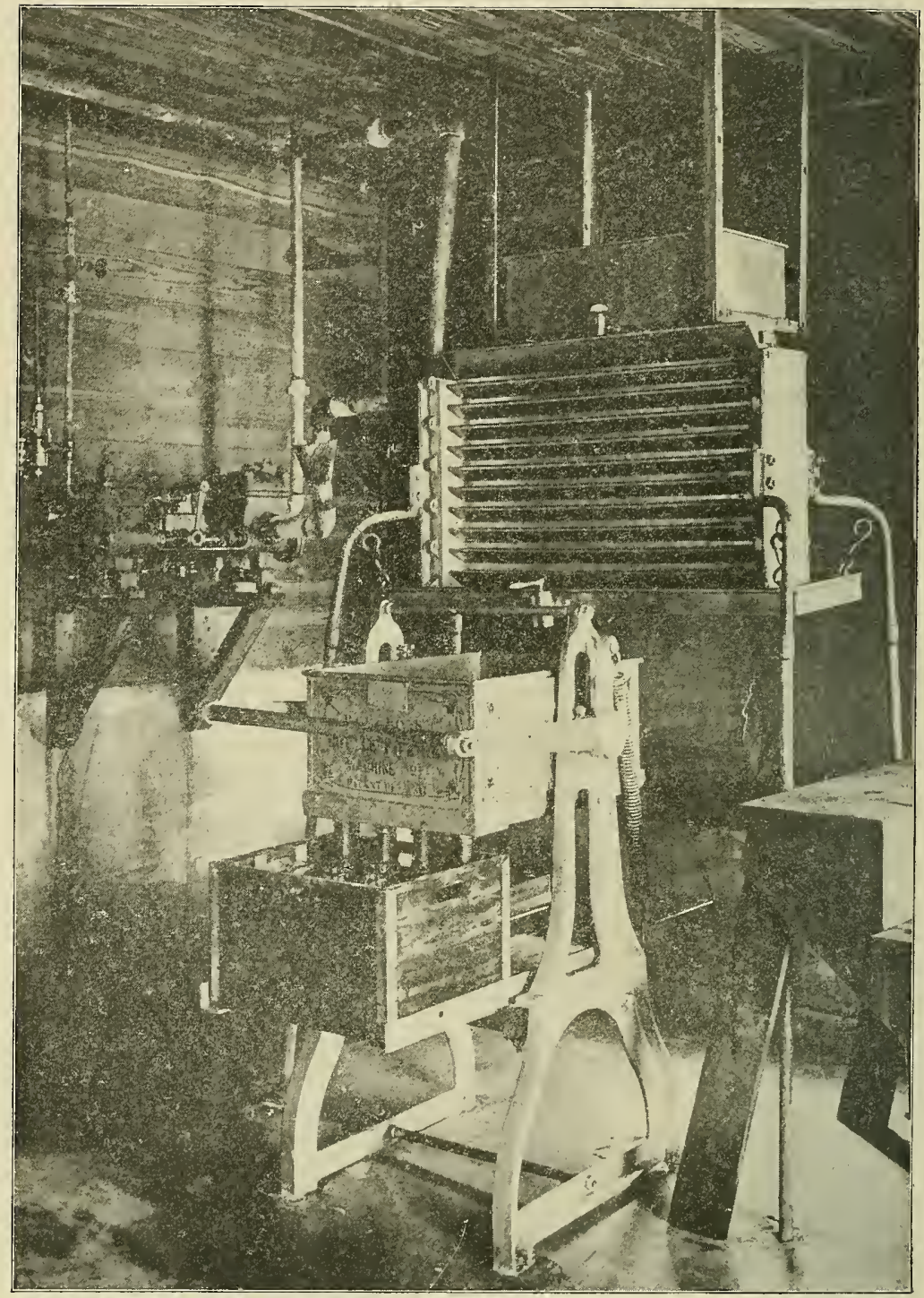

BOTTLING MACHINE AND MILK COOLER. 


\section{BACTERIA IN MILK AND ARTIFI- CIAL REFRIGERA'TION FOR DAIRYMEN.}

Milk when kept moderately warm soon changes so that it becomes unfit for food. These changes are produced mainly by the growth and development within the milk of microscopic plants, ealled bacteria, which break down some of the substances present in milk with the formation of other substances having different physical and chemical properties. Some of the products thus produced may then react with othor empounds present in the milk so that the resulting changes may be and are extremely complicated and difficult to follow even by a chemist. The souring of milk is an example of the best known and simplest change that takes place as a result of bacterial growth. In this ease certain types of bacteria break up the milk-sugar into lactic acid (which gives sour milk its sour taste), and carbon dioxide. The lactic acid formed reacts with the casein of the milk, changing it chemically so that it becomes insoluble and the milk thickens and is said to "lopper."

In milk intended for direct consumption it is extremely desirable to keep the germ content as low as possible for the reason that such milk is a more healthful article of diet. Milk which has many bacteria in it is frequently the cause of diarrhœa and other digestive troubles in small children. This is especially true in hot weather, for then the number of bacteria in common market milk is apt to be very great, and the mortality of babies and small children at its height. By improving the quality of the milk supply of our towns and cities the mortality of children may be materially decreased. That this statement is true is 
clearly shown by the statistics of the Health Department of Rochester, N. Y. Without any supervision of any sort over the milk supplied to the city there died in Rochester during the ten years from 1887 to 1896, inclusive, 7,451 children under five years of age. During the next ten years, or from 1897 to 1906, inclusive, when efficient supervision was exercised over the production and sale of milk, there died only 4,967 children under five years of age. The city, too, contained from 25,000 to 30,000 more people during the last period covered by these statistics, than during the first period, yet the number of children under five years of age that died Aecreased not only relatively, but absolutely, due to the better quality of the milk supply. In this supervision careful bacteriological examinations have played a most important part. Vendors of milk which contains too many bacteria may have their licenses revoked in that city.

Admitting the importance of bacteria as affecting the production and sale of sanitary, healthful milk, let us glance for a moment at the most important ways by which an excessive number of bacteria in milk may be avoided.

The changes which usually take place in milk may be avoided first, by keeping the bacteria completely out of the milk, or second, by destroying those that get in the milk, or, third, by preventing those which almost always are present from developing to such an extent as to cause trouble.

\section{I}

\section{KEEPING BACTERIA OUT OF MILK.}

This is a very difficult thing to do as bacteria are so small that they may be floating in the air and thus come in contact with the milk during the milking process, or particles of dust or dirt, each particle carrying many bacteria, may fall into the milk from the cow's udder or from the hands or clothing of the milker, or bacteria may be present in the milk utensils, or finally, some few bacteria may be present in the milk even before it leaves the cow's udder, the germs having gained access to the 
interior of the udder through the milk ducts. When proper preeautions are taken, however, the number of bacteria that gain access to the milk in these various ways may be very materially reduced, as compared with the numbers prosent in milk as ordinarily prołuced, and in the ease of certified milks in which no expense or labor is spared the germ content may be and is usually very low. In fact in some cases milk has been produced practically free from germs, or nearly sterile. It must be understood, however, that to produce milk with a very low germ content costs considerably more than to produce it carelessly, as the cows have to be washed before each milking, the udders and flanks disinfected, the stable kept perfectly free from dust, the clotling of the milkers sterilized, and all the operations carried out with the utmost care and attention. W. A. Stocking, Jr., quotes figures in the Seventeenth Annual Report of the Storr's Experiment Station, illustrating the germ content of the milk produced by the Purity Milk Company. This milk was examined for bacteria when it was delivered to the customers, or from eight to twentyfour hours old. Ten consecutive counts were taken during the month of December and the average of these determinations was only 273 bacteria per cubic centimeter, or a quarter of a teaspoonful, and he says in discussing these results: "The comparatively low numbers of bacteria found in these 'sanitary' milks at the time of delivery shows beyond a question that it is possible to supply to the consumer milk which carries a relatively low bacterial content." In striking contrast with the low number of bacteria found in sanitary certified milks is the enormous numbers often found in commercial milk when delivered to the consumer, the number frequently ranging from several hundred thousand bacteria to several millions per cubic centimeter. It should be observed here that the dirt content of different samples of milk usually increases quite uniformly with the increase in the number of bacteria, or, in other words, that the dirtiest milk, other things being equal, is usually highest in germs. Consequently the germ content of milk may be used as an indication of the care used in its production. 


\section{KILLING BACTERIA IN MILK.}

Germs present in milk may be destroyed either by heat or chemicals. In practice heat is the only agency used, as any substance poisonous enough to completely destroy all of the germs which may be present in milk would also destroy the usefulness of the milk as food. If the temperature to which the milk is raised is high enough or maintained long enough so that all of the germs and spores present are destroyed, the process is called sterilization. This process is seldom employed on account of the high temperature required which gives to the milk a boiled taste and changes its color. If the temperature used is only high enough to destroy most of the germs which may be present in milk, including disease germs, such as those of tuberculosis, typhoid, etc., the process is called Pasteurization. In many cases Pasteurization is practiced on a large scale. The milk is heated to about $158^{\circ} \mathrm{F}$. and retained at this temperature for fifteen minutes and then cooled rapidly to as low a temperature as practicable.

\section{III.}

RESTRICTING THE GROWTH AND DEVELOPMENT OF BACTERIA IN MIIK.

If the cows are kept thoroughly clean, if the stable is well lighted, well ventilated, and kept in a sanitary condition, if the milkers wear clean clothes, have clean hands and milk into clean pails, it is not difficult to obtain fresh milk which contains, relatively, only a few germs. At ordinary temperatures, however, these increase with wonderful rapidity. To show how rapid this increase may be some figures are selected at random from experiments performed by Prof. Conn, and reported in the Sixteenth Annual Report of the Storr's Experiment Station, pages 39-56: 


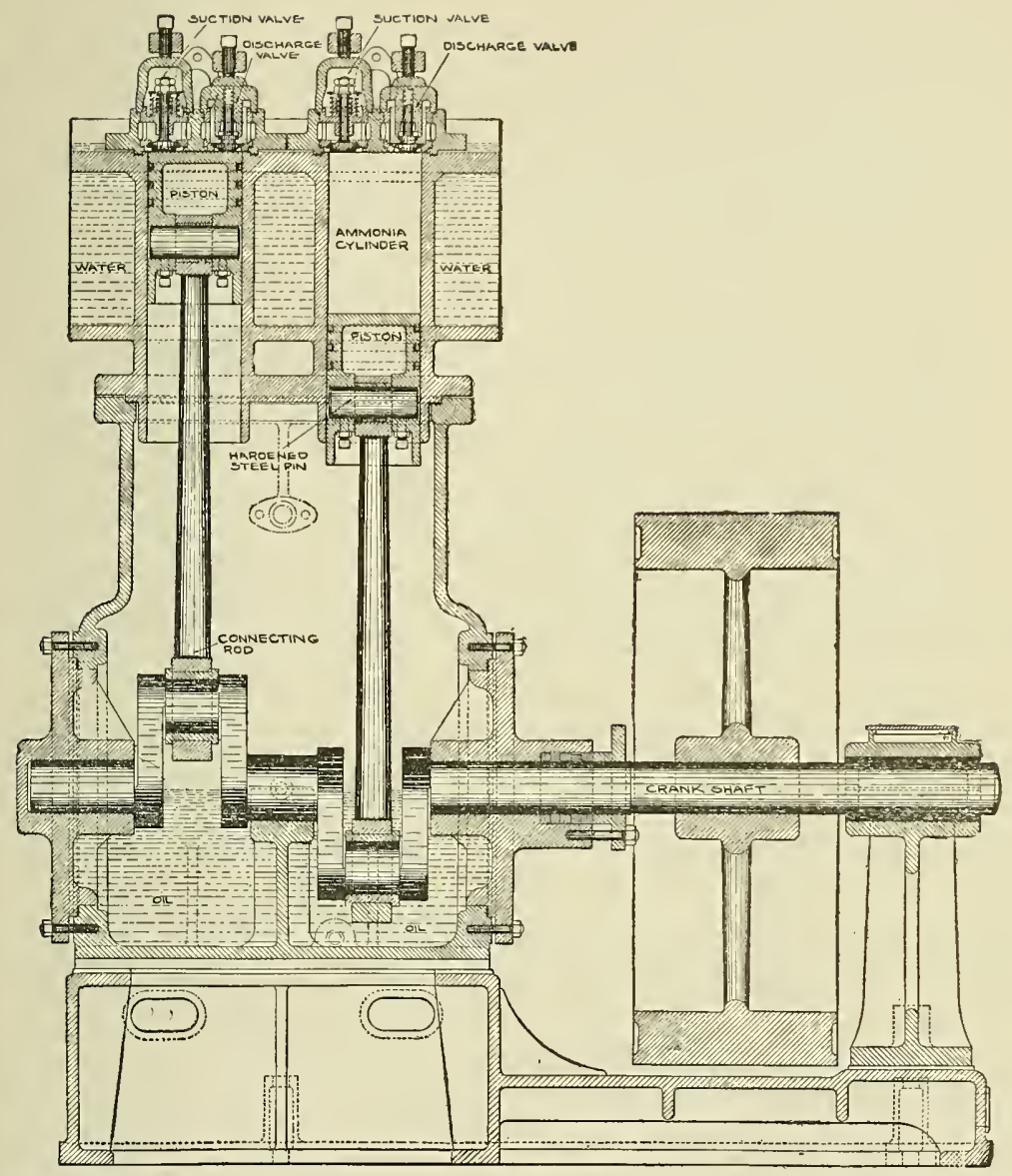

SECTIONAL VIEW-REMINGTON DOUBLE CVIINDER REFRIGERATING MACHINE.

Remington Machine Co., Wilmington, Del. 


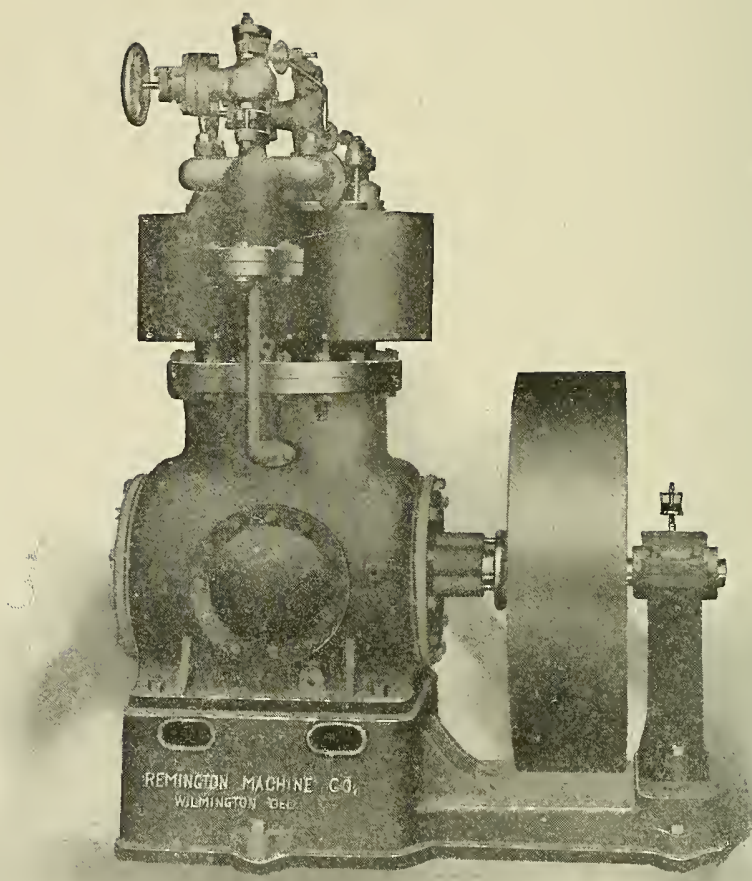

REMINGTON DOUBLE CYLINDER REFRIGERATING MACHINE Remington Machine Co., Wilmington, Del. 
Milk kept at $20^{\circ}$ C. or $68^{\circ} \mathrm{F}$.

\begin{tabular}{|c|c|c|}
\hline Sample & Age of Milk & $\begin{array}{l}\text { Number of } \\
\text { Bacteria per } \\
\text { Cubic Centimeter }\end{array}$ \\
\hline \multirow[t]{2}{*}{1} & 6 hours & 64,000 \\
\hline & 30 hours & $155,000,000$ \\
\hline \multirow[t]{2}{*}{2} & 6 hours & 21,000 \\
\hline & 30 hours & $413,000,000$ \\
\hline \multirow[t]{2}{*}{3} & 6 hours & 47,000 \\
\hline & 30 hours & $2 \cdot 20,000,000$ \\
\hline \multirow[t]{2}{*}{$t$} & 6 hours & 54,000 \\
\hline & 30 hours & $155,000,000$ \\
\hline
\end{tabular}

The table shows that the milk contained from 2,000 to 20,000 times more germs at the end of the $2 \pm$ hours than it did at the beginning. This rapid increase in the number of germs present in milk may be prevented or restricted either by Pasteurization, which destroys those germs easily affected by heat, and which has already been mentioned, or by the use of chemical preservatives, or by keeping the milk at a low temperature.

The use of chemical preservatives is condemned by most authorities. In fact, in most states the use of chemicals for the preservation of milk intended for direct consumption is prohibited by law, as consumers object, and quite properly, to being drugged by their milkmen. The use of preservatives permits the sale of dirty milk which otherwise would spoil quickly on account of its high germ content, and which, instead of being sold for human consumption, should either be fed to animals or dumped into the gutter. Pasteurization and the use of preservatives are both employed to prevent too rapid souring. In the first instance most of the germs present are destroyed by heat, and in the second case they are prevented, to a certain extent, from developing by the chemicals present. By far the better way, however, instead of using either of these expedients is to prevent by means of a low temperature, the multiplication of those few germs which almost unavoidably are present in the milk. 


\section{RESTRICTING THE GROWTH OF GERMS BY KEEPING MILK AT A LOW TEMPERATURE.}

In handling milk commercially for direct consumption the effort is made to cool it as soon as practicable and to retain it at a low temperature until it reaches the consumer. This universal practice is founded on a sound scientific basis. Low temperatures materially hinder, at least for several days, the development of the germs ordinarily present in milk. Milk promptly cooled and maintained at practically a freezing temperature may contain, when six or seven days old, even a less number of germs than the fresh milk, some of the commonly-occurring organisms apparently being destroyed by the low temperature. (Conn.) After the lapse of this time, however, there is a rapid and sometimes enormous increases in the number of germs present in the milk, and although the milk may still remain sweet and uncurdled it may be teeming with innumerable millions of bacteria. The species which develop at low temperatures are quite different from those which thrive at moderate temperatures. Bacterium lactis acidi, which causes the common souring of milk, grows most luxuriantly at a temperature of about $68^{\circ} \mathrm{F}$. and does not develop at all at low temperatures. Milk more than a week or ten days old should be viewed with suspicion even though apparently in good condition. Prof. Conn in the sixteenth Report of the Storr's Experiment Station, after a careful experimental study of this subject, says: "Milk is not necessarily wholesome because it is sweet, especially if it has been kept at low temperatures. At the temperature of an ice chest millk may remain sweet for a long time, and yet contain enormous numbers of bacteria, among which are species more likely to be unwholesome than those that develop at $20^{\circ}$ C. $\left(68^{\circ}\right.$ Fah.). From this standpoint the suggestion arises that instances of ice cream poisoning are perhaps due to the preservation of eream for several days at a low temperature, such treatment keeping the milk sweet, but favoring the development of species of bacteria that are, at higher temperatures, checked by the lactic organisms." 


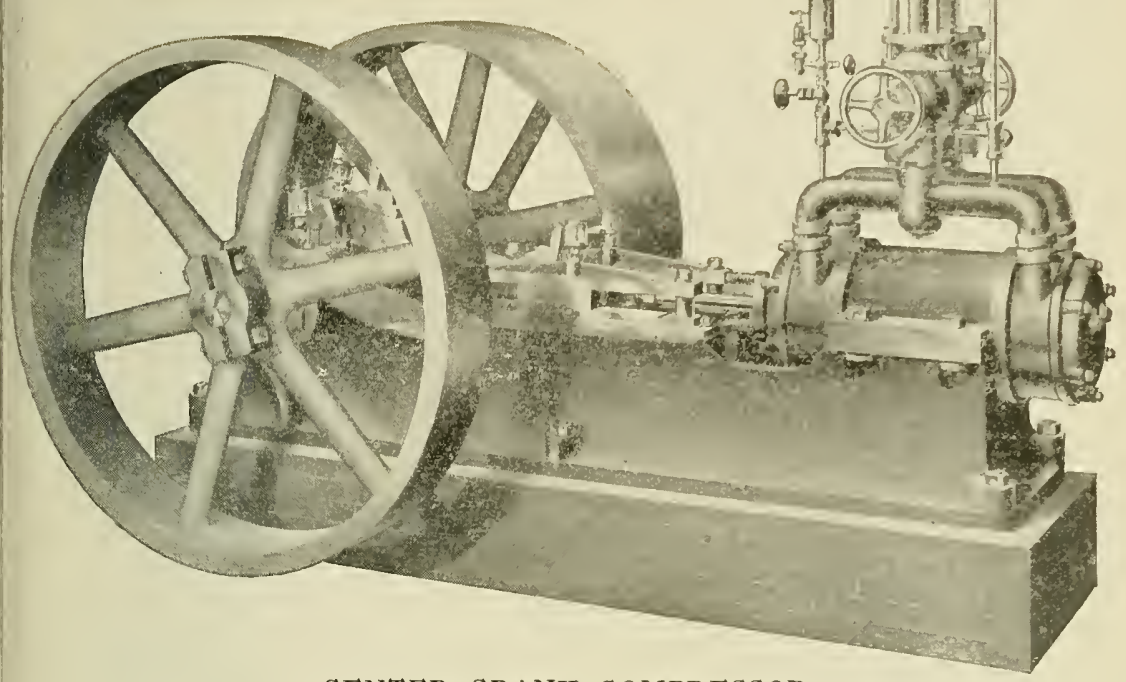

CENTER CRANK COMPRESSOR

Creamery Package Manufacturing Company, Chicago, Ill.

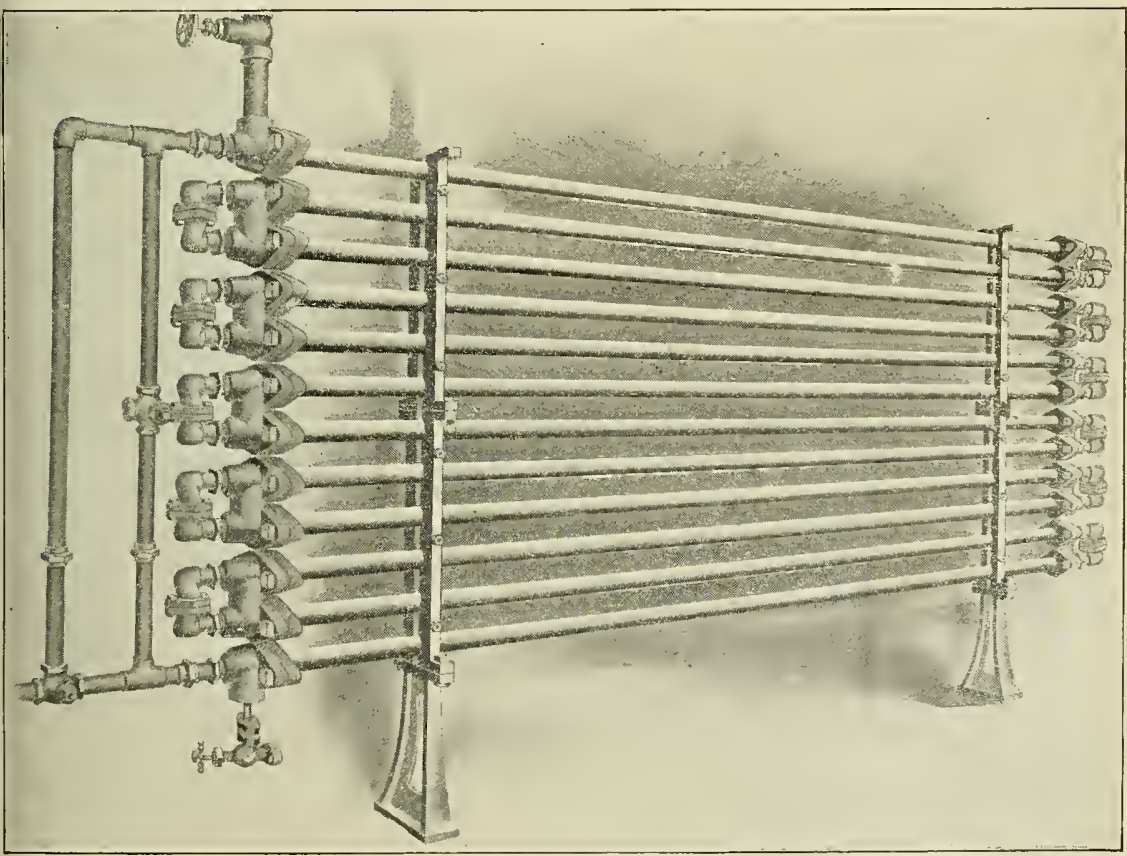

AMMONIA CONDENSER, DOUBLE PIPE TYPE Creamery Package Manufacturing Company, Chicago, Ill. 


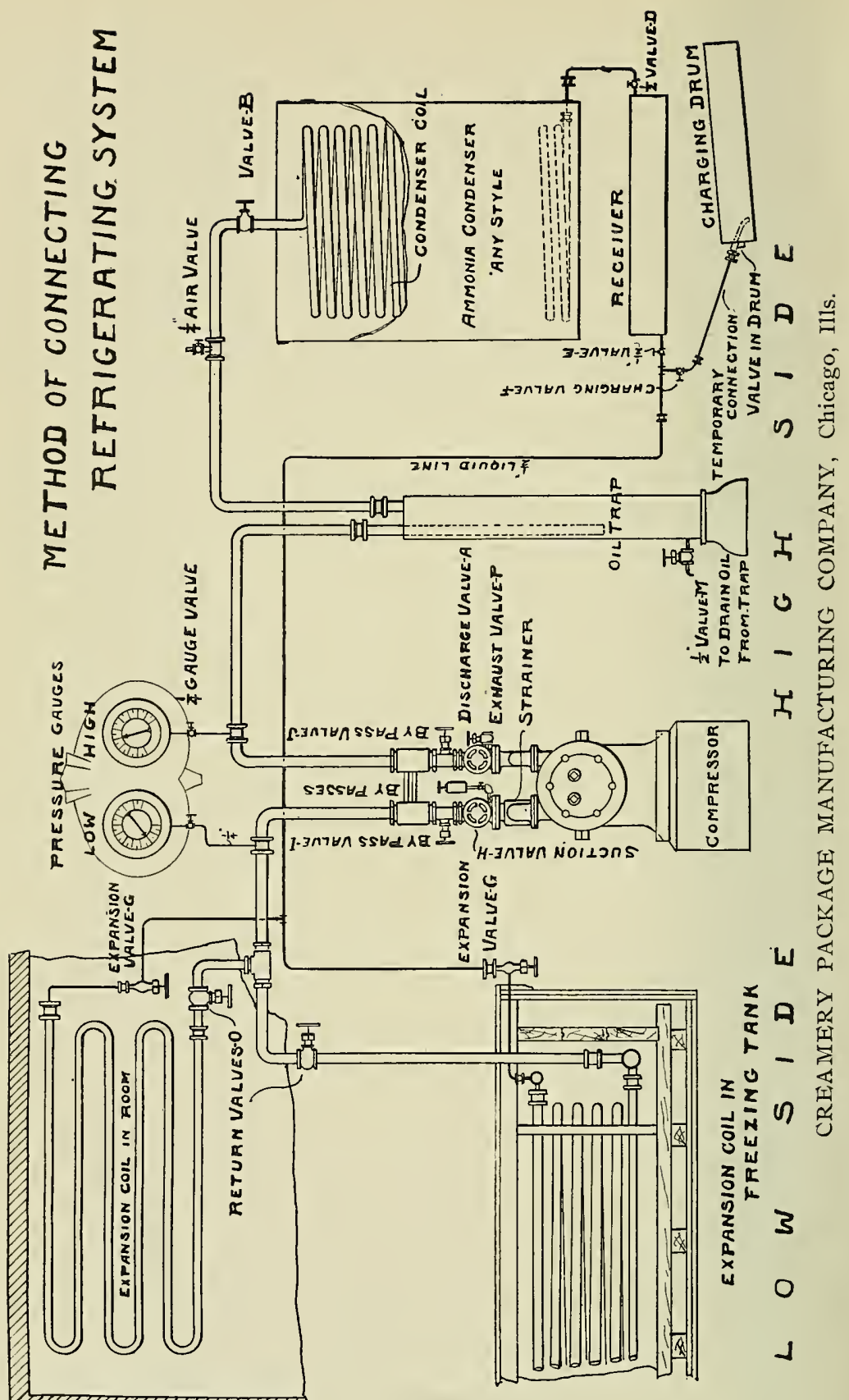


As an example of the influence of different temperatures, as affecting the changes in milk, the following experiment may be cited: On August 30, 1907, some fresh warm milk was divided into two portions. One part was cooled at once, by means of a refrigerating machine, to the freezing temperature, bottled, and then stored in a refrigerator whose temperature averaged about $42^{\circ} \mathrm{F}$. The other portion was bottled while still warm, and kept at the temperature of the air, which averaged at that time about $72^{\circ} \mathrm{F}$. The milk in the refrigerator was sweet, and as far as one could determine by taste, appearance and smell, was practically unchanged when it was two weeks old. The other sample was sour and curdled at the end of the second day.

The poor quality of most of the milk sold in our towns and cities is due not only to unsanitary methods of production, but also to the fact that it is rarely cooled promptly to a temperature low enough to check the development of bacteria. It is usually the case, too, that the more carelessly the milk is produced, the more carelessly it is cooled, if at all, and it is of course unnecessary to observe that the more germs that are allowed to gain access to the fresh milk the more promptly it should be cooled to a low temperature. In many instances the lax methods of cooling are due not so much to carelessness or lack of knowledge on the part of the dairymen, but rather to inadequate facilities for doing this work properly. If water is used with which to cool the milk, either by means of a milk cooler or by setting the cans of warm milk in a tank of water, the temperature to which the milk is reduced is seldom low enough for the efficient preservation of the milk, while, on the other hand, if reliance is placed on ice the supply nearly always runs short at the hottest and most critical time of the year. In addition to this disadvantage the supply of natural ice in parts of West Virginia and throughout the more southern States is uncertain and unreliable and in conducting a milk business precaution should be taken to prevent any factor, such as insufficient means for cooling the milk, from interfering with the constant production and sale of a high grade article. Under ordinary conditions it is expensive to harvest and store the large quantities of ice necessary to cool milk and i.ce it 
properly while transporting it to market and, moreover, the handling and use of ice is one of the most disagreeable duties which a dairyman or creameryman has to perform.

\section{ARTIFICIAL REFRIGERATION FOR DAIRY PURPOSES.}

During the past season the Station has been studying the adaptability of artificial refrigeration for the purposes of the dairy farmer and a small ice machine has been installed with that object in view. With this apparatus the milk from the station herd of about twenty cows is cooled to the freezing temperature as soon as it is milked. It is then bottled and stored in the cold storage room until delivered to the consumers in our local market. Only one delivery is made per day, even in the hottest weather of summer, and the milk bottles are not iced when taken out of cold storage, yet there has not been a single complaint from any of the consumers on account of sour milk, and as the machinery has been run without a single breakdown or accident of any kind for an entire season by a man who has had no previous experience in the handling of machinery, we feel that small refrigerating plants have a big field of usefulness on the better class of dairy farms which supply milk and cream to our towns and cities for direct consumption.

It is true that refrigerating apparatus is somewhat expensive, but by its use several important economies ean be instituted in the handling of milk. In the first place, as already mentioned, only one delivery need be made per day even in hot weather. This is especially important, for in summer the dairy farmer is always busy with his men and teams. Secondly, the quality of the milk is improved by the rapid and thorough cooling and such milk should, and does, command a better price than milk improperly cooled. Thirdly, any surplus milk that is not sold from day to day can be held longer in a marketable condition than if proper cooling facilities were not provided. Fourthly, and finally, when the milk is cooled and hottled at the dairy there is no waste on the part of the driver. The driver of the milk wagon can be rompelled to account for every hottle of milk that he received, 


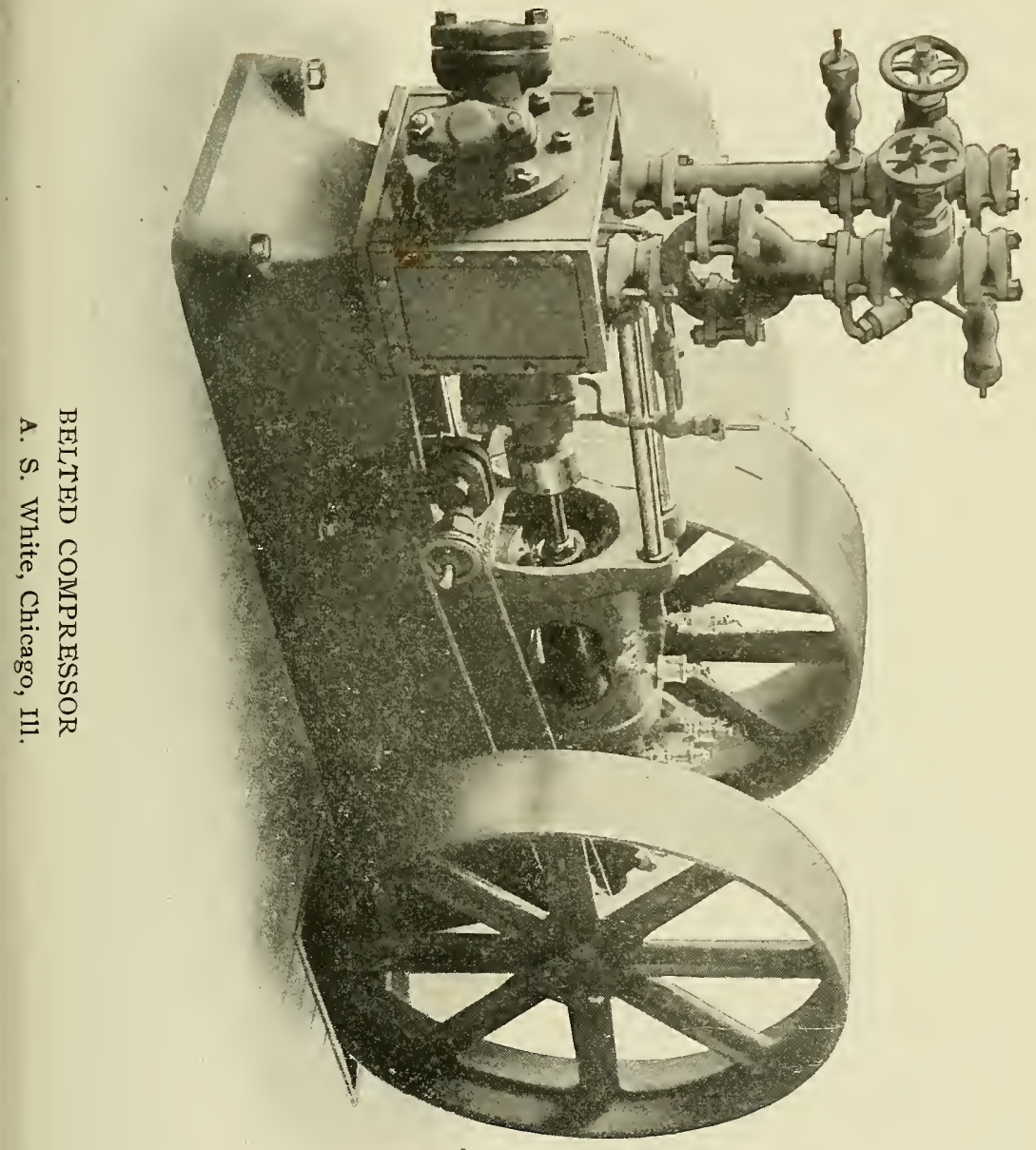




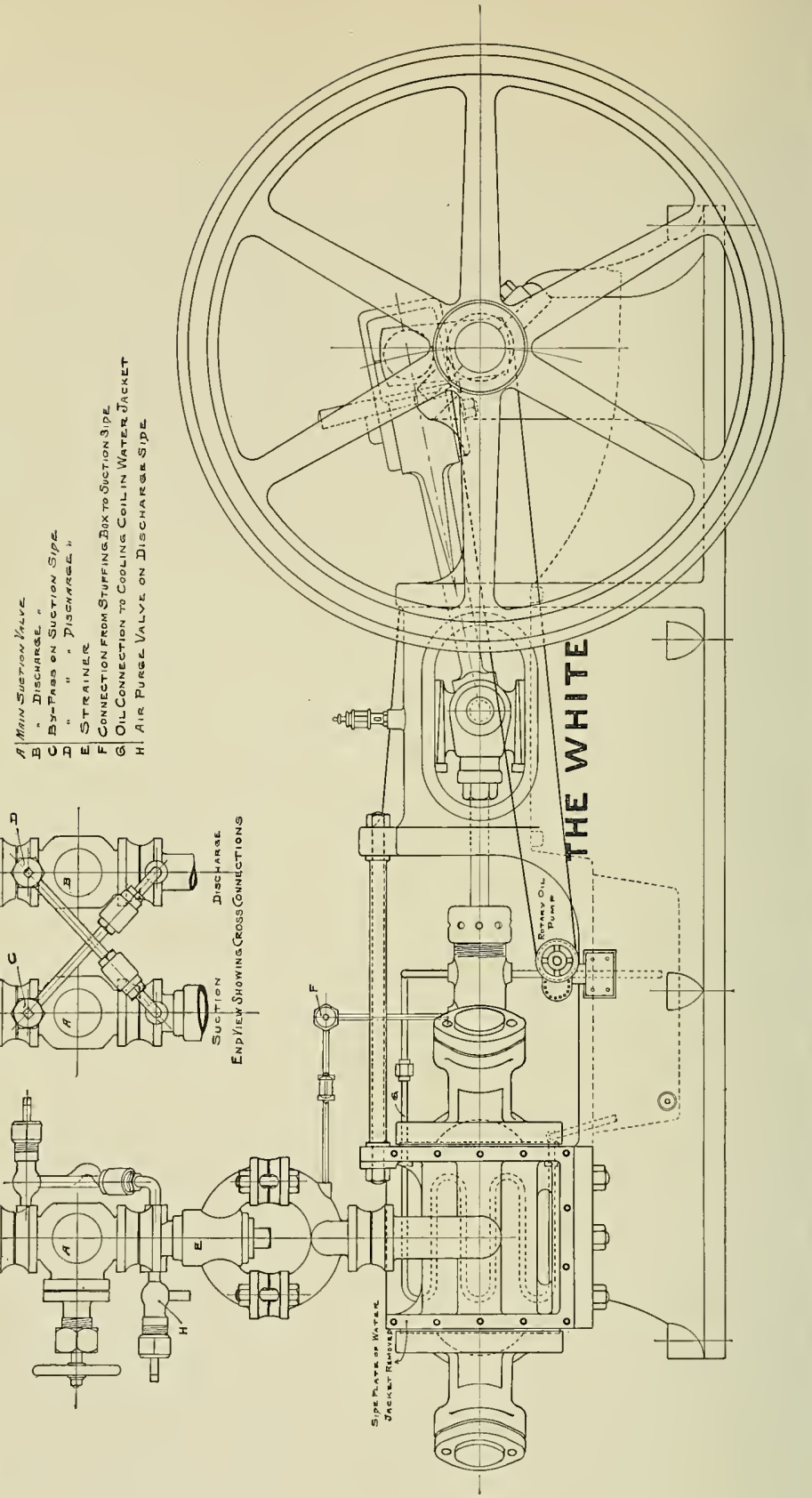

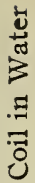

뭉

옹

คํำ

品

范

당

证

환 믐

몽

范

苞雚

语

की

o

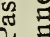

A

$\rightarrow$

告

मे

亗

䓀 
while if milk is dipped from the ean, there is always more or less wastage, amounting frequently to ten per cent or more. To overbalance these factor's in the handling of a milk business is the first cost of the refrigerating machine, the cost of operating it and the cost of repairs.

The cost of repairs should be, and is under ordinary conditions, very small. I have before me the advertisement of an ice machine manufacturer which eontains the statement that machines built twenty-seven years ago are still in operation. These machines must have been among the first ever built in this country. In fact, there is little to wear out in a compressor if the bearings are kept properly lubricated and properly adjusted so as to prevent "lost motion."

The operation of a small refrigerating machine ought not to be expensive as it is unnecessary to employ a skilled mechanic for this purpose, although, of course, the more experience that one has had in the operation of any machine the better. It is the custom of ice machine manufacturers to have their experts install the machinery and operate it for a time until the purchaser becomes sufficiently proficient to operate it alone. This usually takes ten days or two weeks.

It is usually good policy to purchase a machine large enough so that it is necessary to operate it only for a few hours each day. Then it can be arranged so that the operation of the ice machine and the other duties connected with the dairy work, such as washing milk bottles, utensils, churning, ete., can be carried on at the same time. When the work is Jone in this way running the ice machine requires no extra time on the part of the dairyman, and the cost of the fuel necessary to furnish the motive power constitutes practically the only expense of any importance.

The proper size of machine depends on so many factors that no attempt will be made here to give data for its determination. Manufacturers of ice machinery can easily furnish this information when supplied with the requirements in each particular case, viz., the number of gallons of milk to be cooled daily; the size of the cold storage room and the temperature at which this is to be held; whether ice is to be made, and how much; and 
finally, how long a time it is desired to run the machine each tay. Machines are rated in tons of refrigerating capacity; for example, a five-ton machine is one which if operated continuously for twenty-four hours would produce the same refrigerating effect as the melting of five tons of ice.

The machine in use at the Station is of three tons refrigerating eapacity. It is operated about three hours every forenoon for the purpose of cooling a tank of brine. The milk from the Station herd is cooled to the freezing temperature by passing it over a milk cooler through which the cold brine is circulated by means of a pump. With this arrangement the warm milk may be cooled almost instantly to the freezing temperature or even frozen to the sides of the cooler, although, of course, this is not desirable. The brine tank is located in the upper part of a cold storage room, which is about six feet square and ten feet high and keeps this room coll, its temperature averaging from $40^{\circ}$ to $45^{\circ} \mathrm{F}$. in summer. Of course, the temperature of this room could be lowered still further by running the ice machine for a longer time. The milk is cooled and bottled immediately after each milking and then stored in the cold storage room until delivery is to be made. That this is a highly satisfactory and economical way for handling milk intended for direct consumption only those can fully appreciate who have had experience in the old way with its train of complaints from customers whose milk becomes sour during hot weather.

\section{HISTORY AND THEORY OF ICE MACHINES.}

Refrigerating machinery, or machinery for the abstraction of heat, has been invented and put into practical use only in recent years. One of the earliest pioneers in this field of endeavor was Jacob Perkins, of London, England, who constructed in 1834 an ice machine using a volatile liquid. "In this machine of Perkins' ether was vaporized and expanded under the reduced pressure maintained by the suction of a pump; and the heat required for such vaporization was abstractea from the substance to be cooled. The resulting vapor was then compressed by the same 


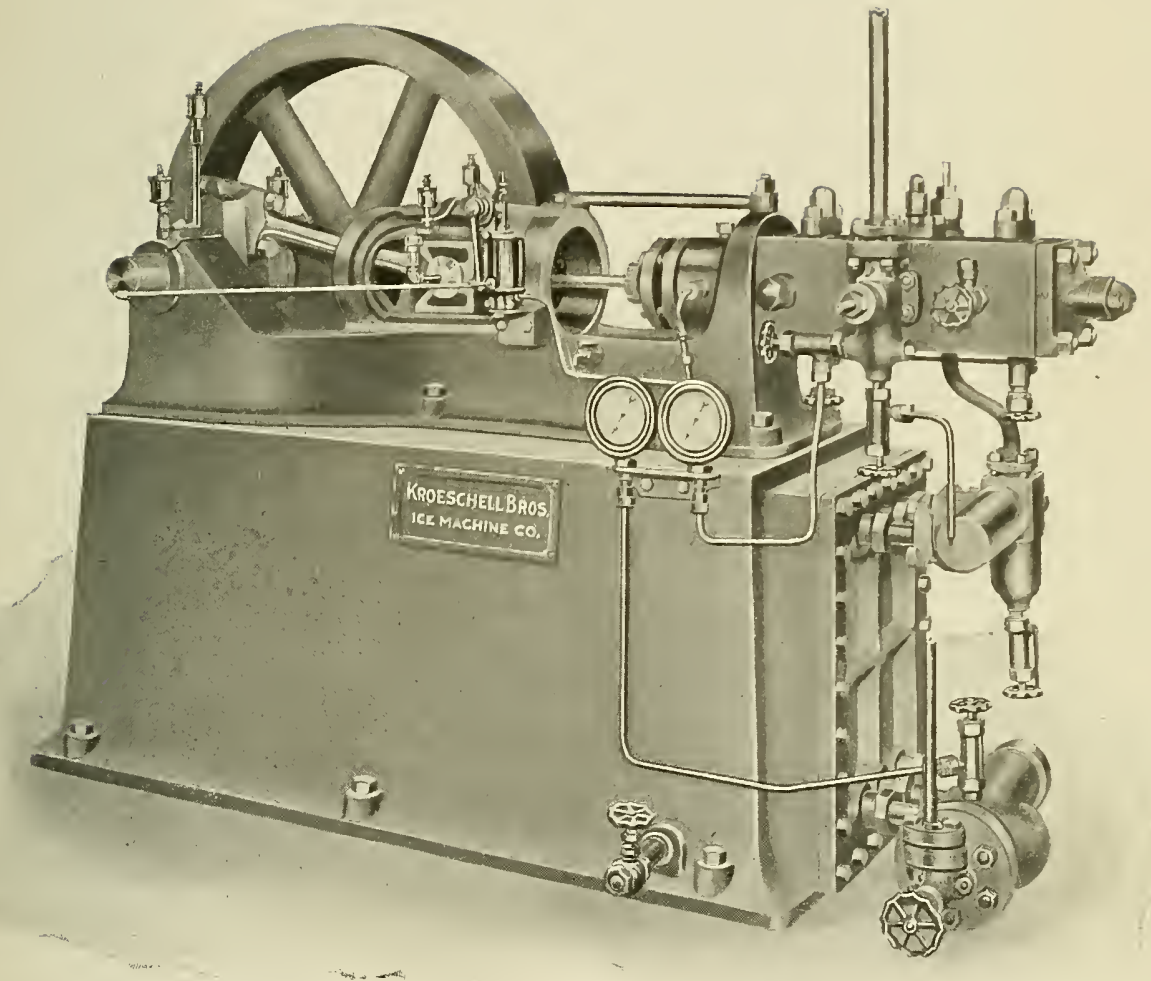

CARBON DIOAIDE REFRIGERATING MACHINE WITH CONDENSER IN SUB BASE.

Kroeschell Brothers, Chicago, Ill. 


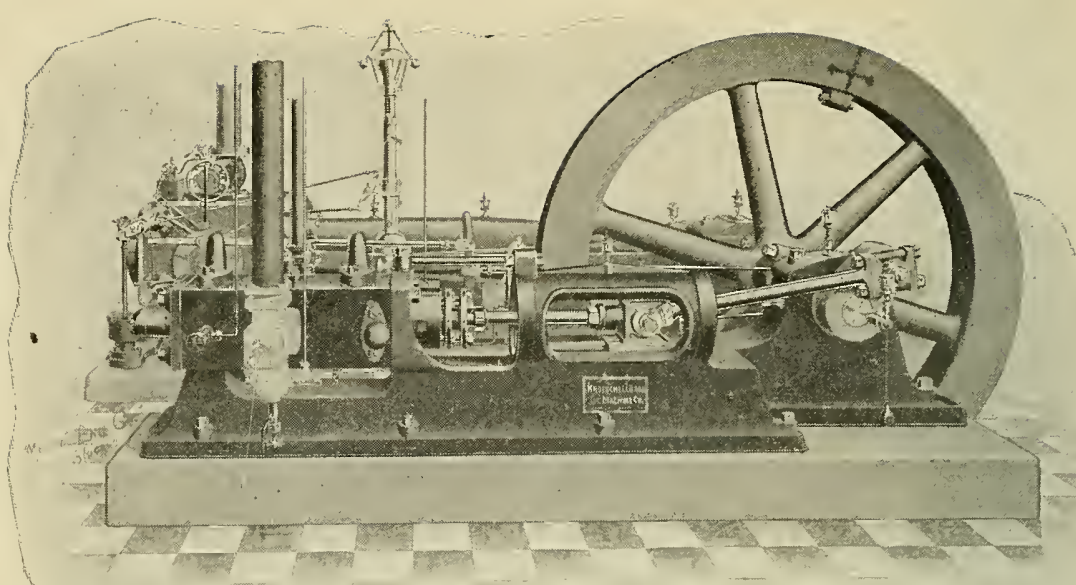

CARBON DIOXIDE COMPRESSOR, Direct Connected to Corliss Engine

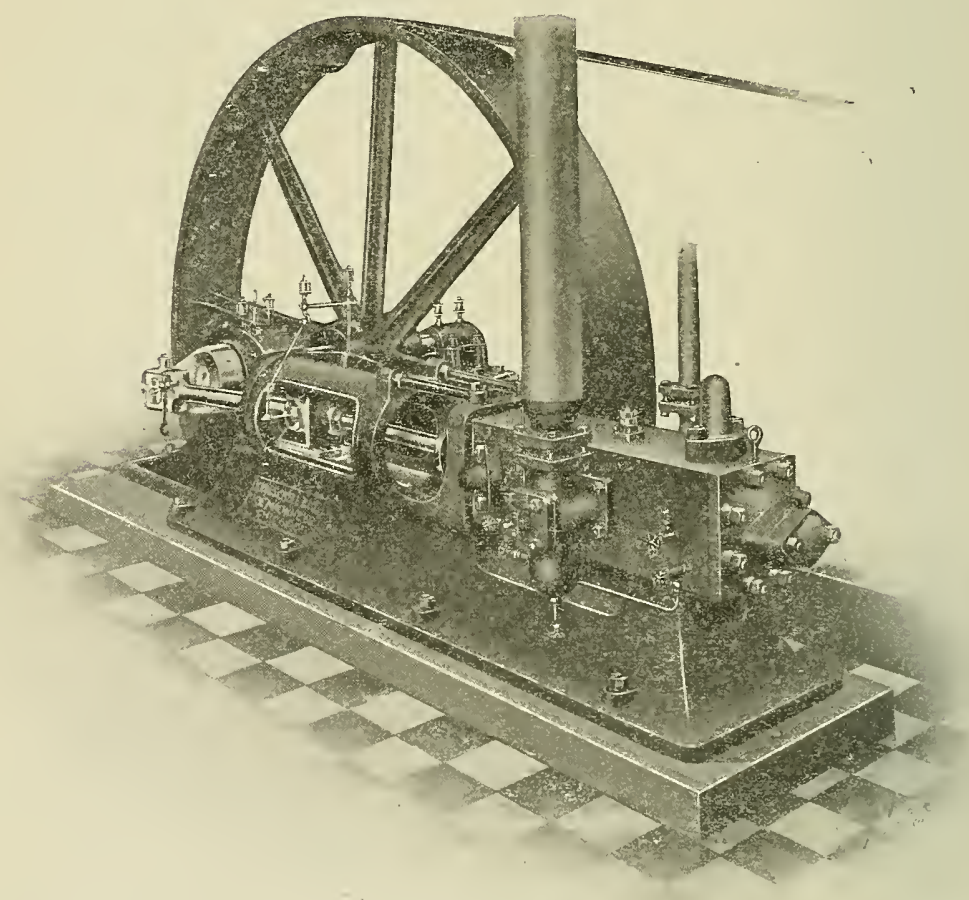

BELT.DRIVEN CARBON DIOXIDE COMPRESSOR Kroeschell Brothers, Chicago, Ills. 
pump into a vessel cooled by water, until under the influence of the increased pressure the vapor parting with heat to the cooling water again condensed to a liquid, and this liquified medium was then ready to be evaporated and expanded over again."

Although Perkins' machine contained all four of the essential features present in all modern compression systems, namely, the evaporator, the compressor, the condenser, and the regulating valve between the condenser and the evaporator, yet his system did not meet with commercial success, and it was twenty-seven years after the date of the original patent, or in 1861, that an ice machine was successfully used in a manufacturing enterprise, although for some years previously a few machines were producing ice on a small scale.

In this development inventors in Australia took a leading part, being stimulated by the demand for a process for preserving, in a fresh coudition, the cheap mutton of that country until landed on the shores of England. "For' use on shipboard compressed air machines were originally employed, but they are now going out of mse, having been supplanted by simpler machines which can be operated more economically.

The first anhydrous ammonia machine of the type commonly used at the present time was patented only twenty-seven years ago by Norman Selfe, a celebrated mechanical engineer, of Sidney, Australia. Since then many patents have been taken out, covering special features or devices for further perfecting, simplifying or cheapening the machinery, but the process remains the same.

As all machinery runs with more or less friction, and as friction produces heat, there could be no possible contrivance of a purely mechanical nature which would have a refrigerating effect. Machinery is used purely and simply for the purpose of circulating a medium by which heat is withdrawn from the material to be cooled and transferre to some other material, which, in practically all cases, is the water used for condensation. In other words, in refrigeration heat is taken from one body and transferred to another. 


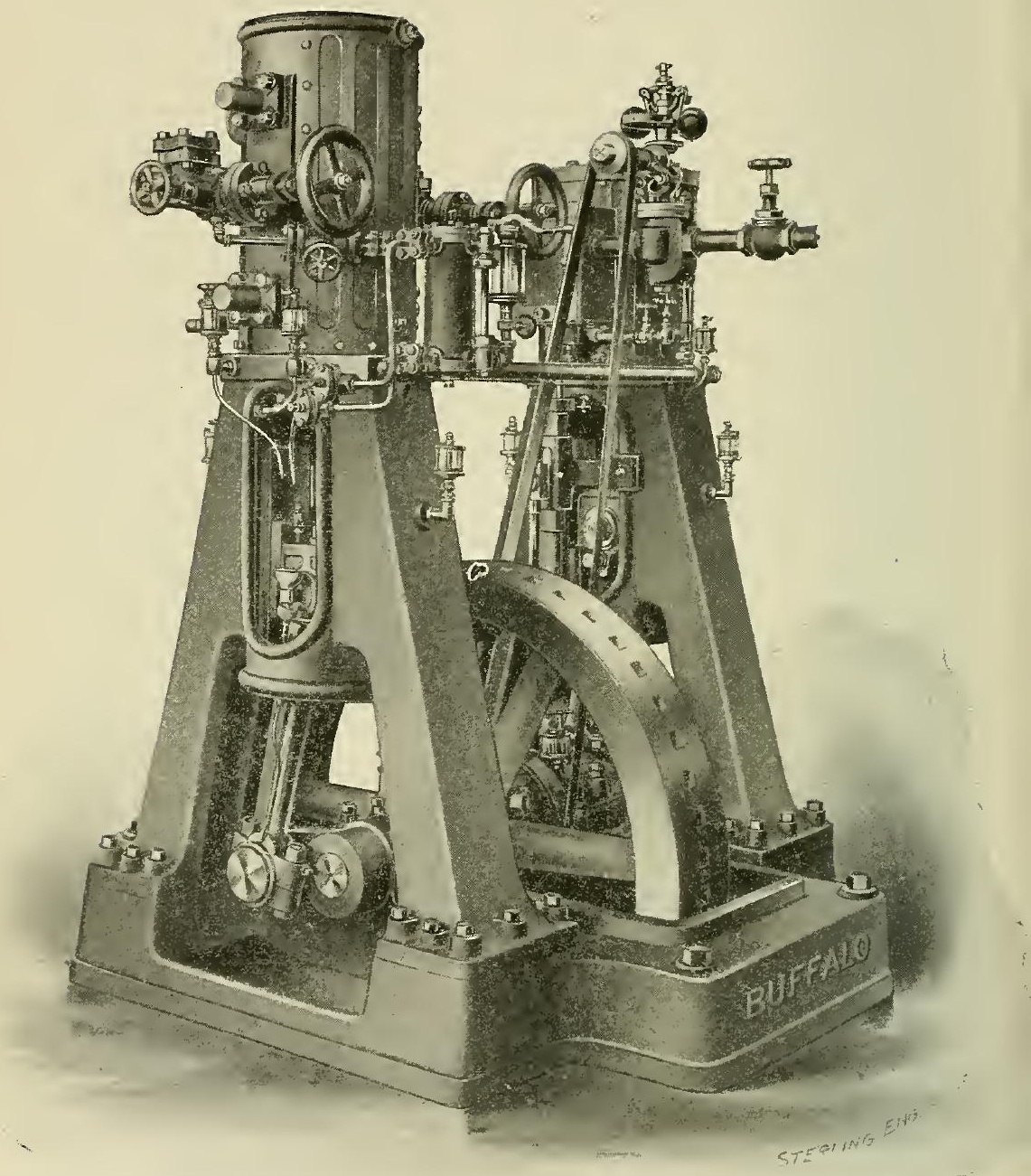

STANDARD 8 and 15 TON STEAM-DRIVEN REFRIGERATING MACHINE Buffalo Refrigerating Machine Company, 126 Liberty St., New York City. 
boiler passes into steam, heat is withdrawn from the furnace or firebox. In an exactly similar nuanner, when ammonia passes from a liquid to a gaseous condition heat is withdrawn from the walls of the enclosing vessel. Water boils or passes into steam at $212^{\circ} \mathrm{F}$. and it must obtain the heat necessary for this change of state from a source hotter than $212^{\circ} \mathrm{F}$. Ammonia boils at $29^{\circ} \mathrm{F}$. below zero, consequently when liquid ammonia is caused or allowed to pass into the gaseous condition, any substance warmer than $29^{\circ} \mathrm{F}$. below zero can furnish heat for this process. Or, in other words, if liquid ammonia be caused to pass into a gas at atmospheric pressure the walls of the enclosing vessel will be cooled to a temperature approximating, theoretically, $29^{\circ} \mathrm{F}$. below zero.

If the preceding paragraphs have been well understood we are now in position to comprehend the practical operation of the commonly used compression system of artificial refrigeration in-which anhydrous ammonia or carbon dioxide is employed.

Although there are quite a large number of compression machines on the market, each differing somewhat from the others, yet they all embody the four essential features shown in the Perkins patent of 1834 , namely, (1) the refrigerator where a volatile liquid, through a reduction in its pressure, is caused to change into a gas, thus absorbing heat, and lowering the temperature of the refrigerator room or the materials to be cooled; (2) the compressor which acts as a pump to draw the gas from the expansion ('oils of the refrigerator and compress it so that it may hecome a licuid again; (3) the condenser where the gas heated by being compressed is cooled by the condensing water ; and finally (4) the expansion or regulating valve which allows the liquid to flash into a vapor through the partial removal of the pressure and with the consequent taking up of heat from the refrigerator or expansion coils, thus completing the cycle.

The compressor is in reality a gas pump whose function is to permit the continuous use of the refrigerating medium. If liquid ammonia or carbon dioxide were cheap enough the expanded gases could be allowed to pass into the atmosphere, thus doing away completely with the compressor, withont affecting in 


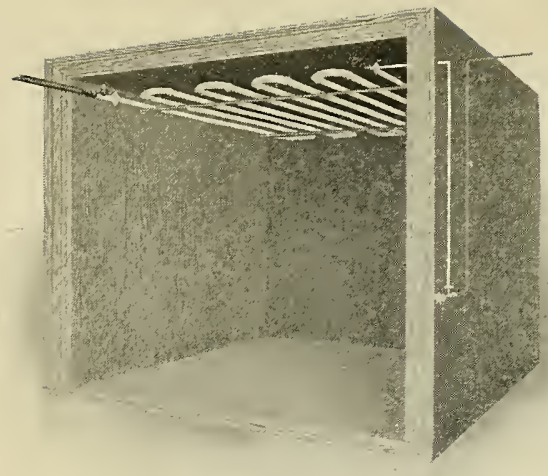

ํo. 1

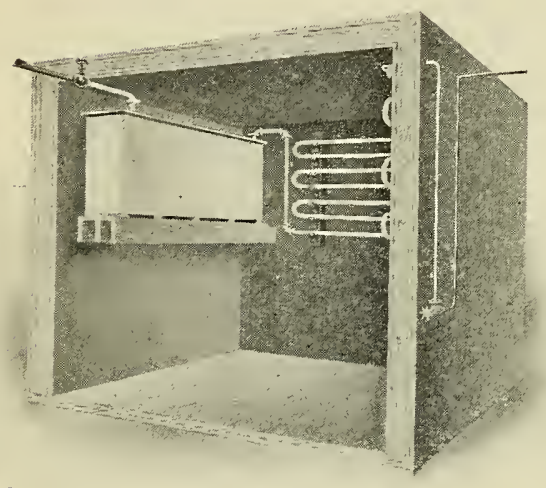

No 3

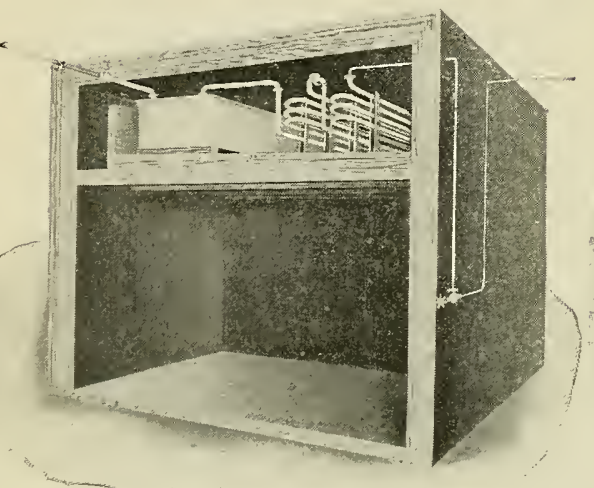

No. 5

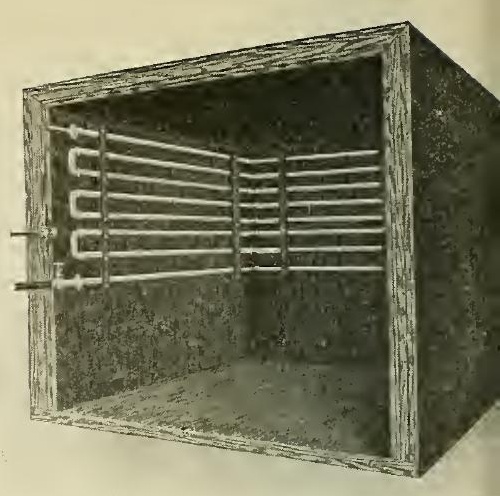

No, 2

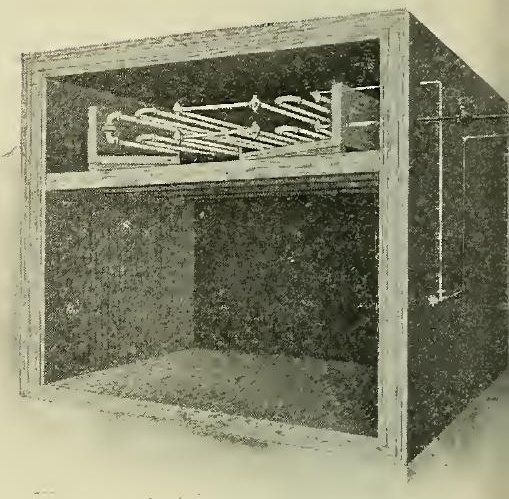

No. 4

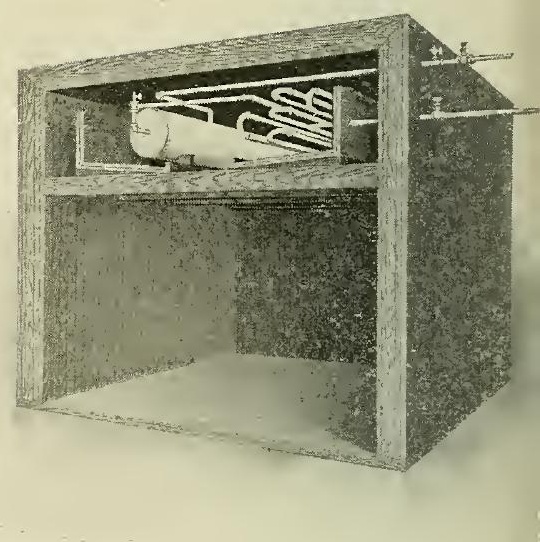

No. 6 
Each ton refrigeration requires from $11 / 2$ to 2 horsepower, according to conditions.

In general allow one ton refrigeration each 24 hours for the following:

$\begin{array}{lr}\text { Water, } & 900 \text { gallons cooled } 40^{\circ} \mathrm{F} . \\ \text { Cream, } & 1700 \text { gallons cooled } 30^{\circ} \mathrm{F} \text {. } \\ \text { Milk, } & 1275 \text { gallons cooled } 30^{\circ} \mathrm{F} .\end{array}$

If it is desired to cool 1,275 gallons of milk $30^{\circ} \mathrm{F}$. and operate the refrigerating machine only 2 hours per łay, then it would be necessary to install a machine twelve times as large as though it were operated continuously, or in this case, a 12-ton machine.

The specific heat of cream is .68 .

The specific heat of milk is .90 .

One cubic foot of milk weighs 64.3 pounds.

One cubic foot of water weighs 62.4 pounds.

One cubic foot of butter weighs 58.7 pounds.

One cubic foot contains $71 / 2$ U. S. gallons.

One U. S. gallon contains 231 cubic inches.

One U. S. gallon contains $8 \frac{1}{3}$ pounds water.

For the ammonia condenser allow $11 / 2$ gallons of water at 60 degrees $F$. per minute per ton of refrigeration.

The number of cubic feet of well insulated space in small storage rooms per ton of refrigeration is as follows:

If held at zero F. 200 cubic feet per ton.

If held at $5^{\circ} \mathrm{F} .400$ cubic feet per ton.

If held at $10^{\circ} \mathrm{F}$. 800 cubic feet per ton.

If held at $20^{\circ}$ F. 1,400 cubic feet per ton.

If held at $32^{\circ}$ F. 2,000 cubic feet per ton.

If held at $36^{\circ}$ F. 2,500 cubic feet per ton.

\section{REFRIGERATOR PIPING.}

\section{By courtesy Creamery Package Manufacturing Company.}

The page opposite shows six methods of piping refrigerator boxes. Which of these is to be used, will depend entirely upon circumstances. If the goods stored are not of a character easily damaged by moisture. the room can be piped on the ceiling, as 
shown in plan 1. Otherwise we pipe the room on the sides as in plans 2 or 3 . We advise, however, that the piping be placed in a loft as in 4,5 and 6 , the lofts forming drip catch pans under the coils. In plans 1, 2 and 4 either brine circulation or direct expansion of ammonia can be used and these arrangements are adopted where the machine is run continuously, or when a rise of 8 or 10 degrees in temperature during a shutdown over night will not injure the goods stored.

In cases where a uniform temperature is desired and the machine is not to be operated 24 hours per day, plans 3 or 5 for direct expansion or plan 6 for brine circulation is advised. Plan 3 is similar to plan 2 except that a rectangular tank, holding several hundred pounds 'of brine, is placed on the side of the room. The ammonia circulates through the exposed coils first and then through the coils submerged in the brine. At the end of each daily run the brine is cooled down to zero or a little above, thus storing sufficient cold to maintain a low temperature while the machine is shut down. The success of this system depends upon the thorough insulation of the refrigerator walls.

In plan 5 the coils and tank are placed in a loft, the air circulating up a flue at the left, then across the brine tank through the coils and down again to the room through a flue at the right. This gives a very dry atmosphere as well as low temperature.

Plan 6 consists of coils and closed brine tank through which cold brine is circulated. It is especially adapted for department store work where the compressor, brine tank and all ammonia piping are compactly located in the basement, and the refrigerators are on the upper floors. The machine needs to be operated but from 5 to 14 hours daily, depending on conditions, and there is no ammonia piping in the boxes. For convenience we tabulate below the uses to which each plan of piping is especially adapted.

Plan 1. For breweries, fish storage, ice storage rooms, also vestibules of cold storage rooms, and any place where moisture does no damage. Either brine or direct expansion.

PLAN 2. For large and small storage houses. Intended for continuous operation. Either brine or direct expansion. 

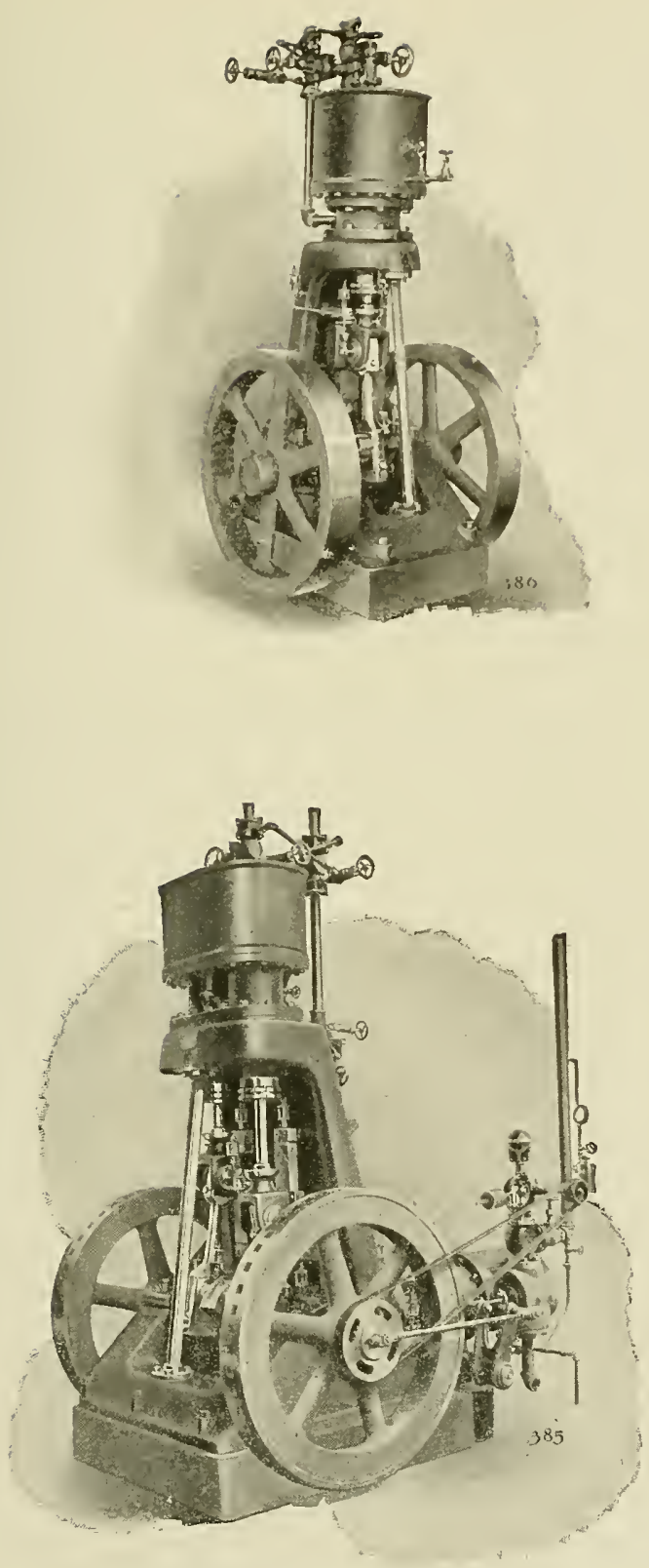

AMMONIA COMPKESSORS

York Manufacturing Co., York, Pa. 


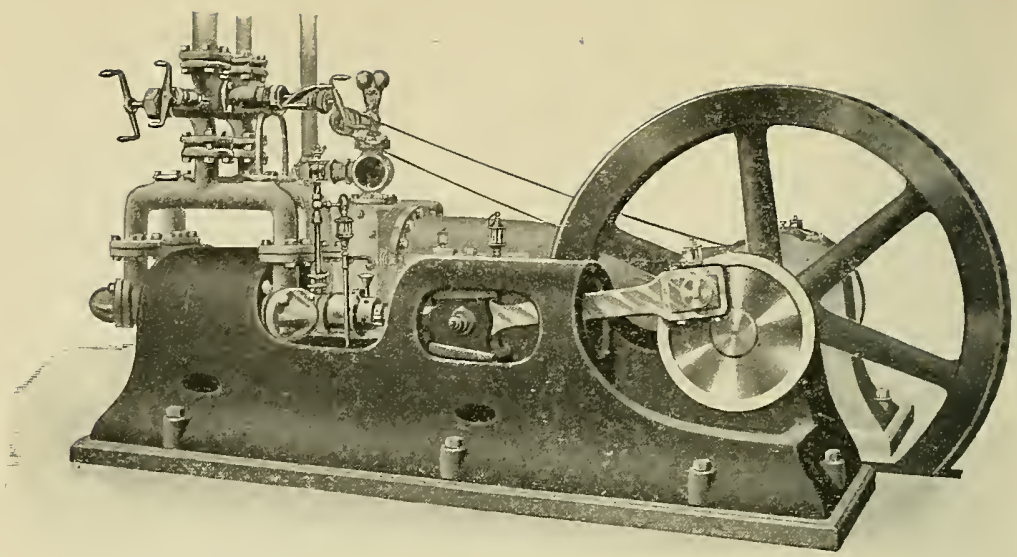

HORIZONTAL, COMPRESSOR

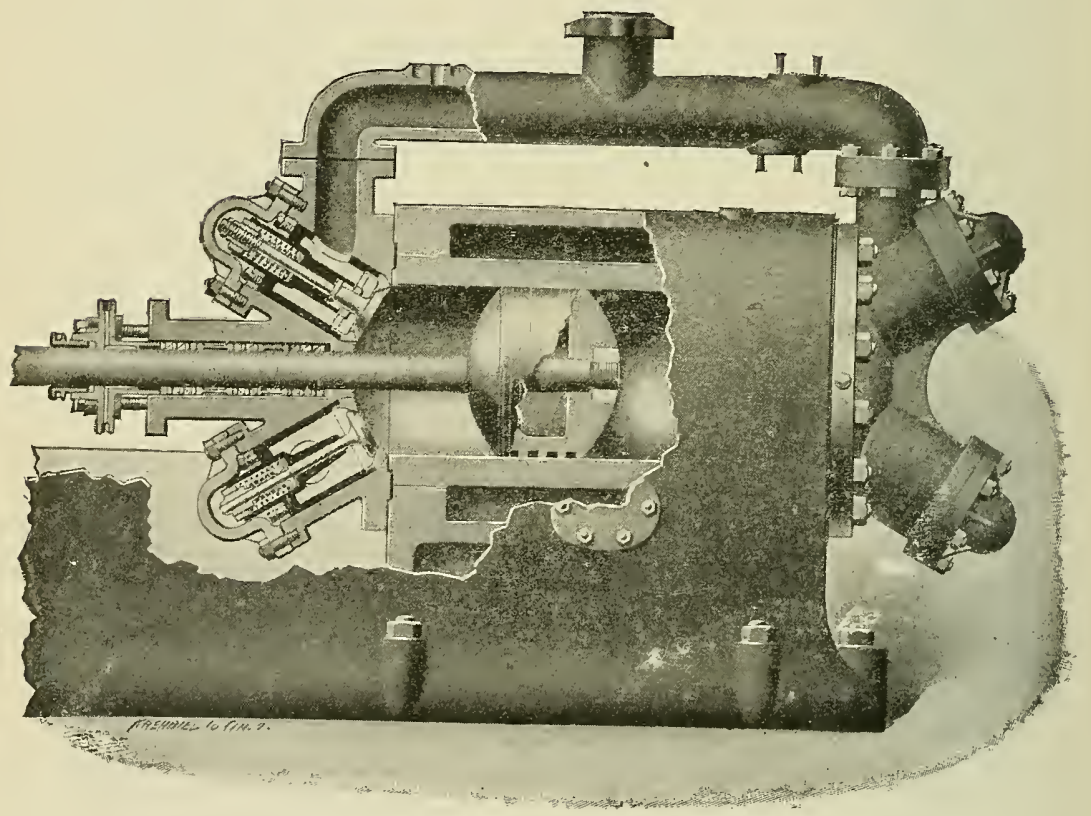

THE PISTON CONSTRUCTION

The Triumph Ice Machine Co., Cincinnati, Ohio. 
PLAN 3. For small storage rooms, in asylums and public institutions, grocery houses, provision stores, ete. For intermittent operation. Direct expansion only.

PLAN 4. For large and small boxes, hog chill rooms, department stores, cold storage rooms. Gives very dry atmosphere. Continuous operation. Either brine or direct expansion.

PlaN 5. For butcher boxes, creameries, llotel storage rooms and small plants generally. For intermittent operation. Direet expansion only.

PlaN 6. For department stores and wherever objection is made to ammonia piping in rooms and machine cannot be run continuously.

\section{INSULATION.}

Practically all dairies or creameries using refrigeration, either for cooling milk intended for direct consumption or for general creamery purposes, find it necessary to fit up storage rooms, where milk, cream or butter can be held at a low temperature. To properly insulate the walls of a room so that a low temperatire can be maintained economically is not such an easy matter as one inexperienced in this line of work might be led to believe. To properly construct even a small cold storage room is both somewhat difficult and expensive. Cooper, in his work on Practical Cold Storage, says: "The additional cost of the insulation (in cold storage houses) may generally be taken as one-half to two-thirds the cost of the building proper. Generally speaking, the cost of insulation erected in place for temperatures of 30 degrees $\mathrm{F}$. down to 0 degrees $\mathrm{F}$. will be from about 25 cents up to 50 cents per square foot in proportion to the above temperatures.

The old style insulation usually contained dead air spaces, or spaces filled with sawdust, shavings, or similar materials, interspersed between various thicknesses of boards and building paper, the walls built up in this way being one foot or more thick. The more recent practice, however, seems to incline toward the use of materials especially prepared for insulating purposes, suclz 
as hair felt, granulated cork boards, or mineral wool blocks. These are usually fastened in place and then covered with a waterproof material or with two thicknesses of boards with insulating paper between. The doors of cold storage rooms, especially, are difficult to construct so that they can be closed tightly on account of the swelling of the lumber in the door itself, or in the walls of the refrigerator, and it is usually good practice to purchase these ready made from the concerns that make a specialty of their manufacture.

The following lists of manufacturers of ice machines, insulating material, cold storage doors, etc., will be found helpful to those who contemplate installing a system of artificial refrigeration:

\section{REFRIGERATING AND ICE MAKING MACHINERY.}

Althoff Mfg. Co., Denver, Colo.

American Linde Refrigeration Co., New York City.

American Machine Co., Louisville, Ky.

American Refrigerating Machine Co., Chicago, Ill.

Arctic Machine Co., Canton, Ohio.

Boland Mfg. Co., Chicago.

Brown-Cochran Co., Lorain, Ohio.

Brunswick Refrigerating Co., New Brunswick, N. J. Buffalo Refrigerating Machine Co., Harrison, N. J. Carbondale Machine Co., Carbondale, Pa.

Castle Ice Machine Co., Indianapolis, Ind.

Clayton, Geo. L., Seattle, Wash.

Cleveland Ice Machine Co., Cleveland, Ohio.

Creamery Package MIfg. Co., Chicago, Ill.

De La Vergne Machine Co., New York City.

Featherstone Foundry \& Machine Co., Chicago, Ill.

Frick Co., Waynesboro, Pa.

Great Lakes Engineering Works, Detroit.

Healy Ice Machine Co., Chicago, Ill.

Huetteman \& Cramer Co., Detroit, Mich.

Ice and Cold Storage Machine Co.. St. Louis, Mo. 
Isbell-Porter Co., Newark, N. J.

Keystone Engineering Co., Philadelphia, Pa.

Kroeschell Bros. Ice Machine Co., Chicago.

Larsen Ice Machine Co., Chicago.

Larsen-Baker Ice Machine Co., Omaha, Neb.

MacDonald, C. A., Chicago, Ill.

Maynard, J. F., St. Louis, Mo.

Mechanical Refrigerating Co., Camden, N. J.

Niebling, The F. W. Co., Cincinnati, Ohio.

Rebsamen \& Almeroth, Chicago, Ill.

Remington, Machine Co., Wilmington, Del.

Roelker, H. B., New York City.

Ruemmeli-Dawley Mfg. Co., St. Louis, Mo.

Triumph Ice Machine Co., Cincinnati, Ohio.

U. S. Pliable Plate Ice Co., New York.

Vilter Mfg. Co., Milwaukee, Wis.

Vogt, Henry, Machine Co., Louisville, Ky.

Vulcan Iron Works, San Francisco, Cal.

Wegner Machine Co., Buffalo, N. Y.

White, A. S., Lake and La Salle Sts., Chicago, Ill.

Wolf, Fred W., Co., Chicago, Ill.

York Mfg. Co., York, Pa.

\section{INSULATING MATERIALS.}

Armstrong Cork Co., Pittsburg, Pa.

Banner Rock Products Co., Alexandria, Ind.

Baeder, Adamson \& Co., Philadelphia, $\mathrm{Pa}$.

Bird, F. W. \& Son, East Walpole, Mass.

Bird, J. A. \& W. \& Co., Boston, Mass.

Cabot, Samuel, Boston, Mass.

Christy \& Huggins Co., Murfreesboro, Tenn.

Columbia Mineral Wool Co., Chicago, Ill.

Johns-Manville, H. W. Co., New York City.

Johnson, John \& Co., Detroit, Mich.

Livezey, John R., Philadelphia, Pa.

Nonpareil Cork Works, New York City. 
Schillinger Bros. Co., Columbus, Ohio.

Shavings \& Sawdust Co., Chicago, IIl.

Standard Paint Co., New York City.

Union Fibre Co., Winona, Minn.

United Cork Companies, Brooklyn, N. Y.

\section{DOORS, COLD STORAGE.}

Gloekler, Bernard, Pittsburg, Pa.

Jones Cold Storage Door Co., Hagerstown, Md.

Stevens, B. A., Co., The, Toledo, Ohio.

Stevenson Co., Chester, Pa.

\section{BOOKS ON REFRIGERATION.}

Compend of Mechanical Refrigeration. (7th Edition.) By J. E. Siebel. Chicago. Flexible Moroceo, $\$ 4.00$; Cloth, $\$ 3.50$.

Machinery for Refrigeration. By Norman Selfe. Chicago. Moroceo, $\$ 4.50$; Cloth, $\$ 3.50$.

Practical Cold Storage. By Madison Cooper. Chicago. Moroceo, $\$ 4.50$; Cloth, $\$ 3.50$.

Indicating the Refrigerating Machine. By Gardner $\mathrm{T}$. Voorhees: Chicago. Flexible Morocco, \$1.50; Cloth, \$1.00.

Refrigeration Memoranda. (4th Edition.) By John Levey. Chicago. Flexible Moroceo, 75 cents.

Principles and Practice of Artificial Ice Making and Refrigeration. (2nd Edition.) By Louis M. Schmiat. Philadelphia. $\$ 2.50$.

Theoretical and Practical Ammonia Refrigeration. (2nd Edition.) by Iltyd I. Redwood. New York. \$1.00.

Ice Making Machines. (Theory of Action.) By M. Ledoux. New York. 50 cents.

Modern Refrigerating Machinery. By Hans Lorenz, II. M. Haven and F. W. Dean. New York. Cloth, \$4.00.

Refrigerating and Ice Making Machinery. (3rd Edition.) By A. J. Wallis-Taylor. London. Cloth, $\$ 3.00$.

Refrigerating, Cold Storage and Iee Making. By A. J. Wallis-Taylor. London. Cloth, \$4.50. 
l'ocketbook of Refrigerating and Ice Making. By A. J. Wallis-Taylor. New York. Cloth, \$1.50.

Refrigerating Machinery and Its Management. By A. Ritchie Leask. London. Cloth, $\$ 2.00$.

Mechanical Refrigeration. By Hal Williams. London. Cloth, $\$ 3.00$.

Refrigeration in the Dairy. By Loudon M. Douglas. London. Clotlı, $\$ 1.00$.

Any of these books sent prepaid on receipt of price. Nickerson \& Collins Co. 315 Dearborn Street, Chicago.

\section{TRADE JOURNALS.}

Ice and Refrigeration, Chicago, Ill.

Cold Storage and Ice Trade Journal, 116 Nassau Street, New York City. 
